\title{
Supporting Sustainability Through Developing a Learning Network Among Traditional Food Producers: Applications of Action Learning
}

\author{
Paul Coughlan \\ Trinity College Dublin, Ireland, coughlnp@tcd.ie \\ David Coghlan \\ Trinity College Dublin, Ireland, dcoghlan@tcd.ie \\ Denise O'Leary \\ Technological University Dublin, denise.oleary@tudublin.ie \\ Follow this and additional works at: https://arrow.tudublin.ie/tfschhmtart
} Part of the Business. Administration, Management, and Operations Commons, Community-Based
Lee next page for additional authors
Learning Commons, Educational Sociology Commons, Entrepreneurial and Small Business Operations Commons, Organizational Behavior and Theory Commons, Organization Development Commons, and the Scholarship of Teaching and Learning Commons

\section{Recommended Citation}

Coughlan P., Coghlan D., O'Leary D.F., Rigg C. and Barrett D. (2016) Supporting Sustainability through Developing a Learning Network among Traditional Food Producers: Applications of Action Learning in Organizing Supply Chain Processes for Sustainable Innovation in the Agri-Food Industry (Organizing for Sustainable Effectiveness, Volume 5) Emerald Group Publishing Limited, pp. 59 - 81 Vol 5, 59-81. Emerald: Bingley, UK. doi:10.1108/S2045-060520160000005011

This Article is brought to you for free and open access by the School of Tourism \& Hospitality Management at ARROW@TU Dublin. It has been accepted for inclusion in Articles by an authorized administrator of ARROW@TU Dublin. For more information, please contact arrow.admin@tudublin.ie, aisling.coyne@tudublin.ie, gerard.connolly@tudublin.ie. Funder: European Commission 


\section{Authors}

Paul Coughlan, David Coghlan, Denise O'Leary, Clare Rigg, and Doireann Barrett 


\title{
CHAPTER 3
}

\section{SUPPORTING SUSTAINABILITY THROUGH DEVELOPING A LEARNING}

NETWORK AMONG TRADITIONAL FOOD PRODUCERS:

\section{APPLICATIONS OF ACTION LEARNING}

\author{
Paul Coughlan \\ Professor in Operations Management \\ Trinity Business School, Trinity College Dublin \\ College Green \\ Dublin 2, Ireland \\ +35318962327 \\ coughlnp@tcd.ie \\ David Coghlan \\ Professor Emeritus \\ Trinity Business School, Trinity College Dublin \\ College Green \\ Dublin 2, Ireland \\ +35318962323 \\ dcoghlan@tcd.ie \\ Denise O'Leary \\ Post Doctoral Research Fellow \\ University College Dublin \\ Belfield \\ Dublin 4, Ireland \\ +35317166451 \\ Denise.oleary@ucd.ie \\ Clare Rigg \\ Senior Lecturer \\ University of Liverpool Management School \\ Liverpool, UK \\ +4401517958361 \\ clare.rigg@liverpool.ac.uk \\ Doireann Barrett \\ Founder/Owner \\ The Gluten Free Kitchen Company Ltd. \\ Tralee, Co. Kerry, Ireland \\ doireannbarrett@thegfkitchenco.ie
}




\begin{abstract}
Purpose: The chapter describes and reflects upon an EU-funded research initiative, TRADEIT, which has attempted to develop a learning network among European traditional food producers as one way of contributing to the economic sustainability of the ventures, the social sustainability of the food's regional character, and the environmental sustainability of food production through the use of traditional methods.
\end{abstract}

Design/methodology/approach: The chapter describes TRADEIT before moving on to an exploration of learning in organizations and networks. It outlines the action learning research methodology developed and implemented to explore the development of a learning network in TRADEIT. A single case history is presented to illustrate the engagement of a small food producer in the network.

Findings: The discussion reflects on the application of action learning in supporting sustainability evident in TRADEIT.

Originality/value: The chapter focuses on the application of action learning in the development of a learning network among traditional food producers across Europe.

Keywords: Learning network; action learning; traditional food producers, sustainability Paper Category: Action learning 


\section{INTRODUCTION}

There are many definitions for the term "traditional food producers." Traditional food is produced in a certain area, which can be national, regional, or local. A traditional food product is authentic in its recipe (mix of ingredients), origin of raw material, and/or production process. Finally, a traditional food product is part of the gastronomic heritage of a local and regional identity. The food industry is "for the people, of the people, by the people." Traditional food companies are also in many ways more sustainable than large food companies. Because of their local markets and suppliers, there are often reduced transportation requirements.

However, closeness to the land (and environment), population health, and regional identity bring particular sustainability challenges to the issue. Sustainability includes economic, social, and environmental dimensions. Each has distinctive indicators of performance and all are inter-related. Concepts, such as the triple-bottom-line, relate to these dimensions and many firms include performance along these dimensions in their strategic plans (Savitz \& Weber, 2006). While traditional food producers may be ideas-rich, they may also be resource-poor. As small, often family, ventures, they may not have the breadth of skills to maintain currency with market trends and regulatory changes. As regional tastes can be distinctive, they may attract consumers from outside the region but have neither the production capacity nor the distribution network to satisfy that demand. While challenged to meet 21 st century standards, including food safety and labelling, they may be constrained in the adoption of technologies and techniques. Finally, they may be so concerned with to managing to survive and compete for today, that they cannot divert resources to managing for tomorrow. In that event, their economic sustainability is at risk with all the negative consequences for social and, indeed, environmental sustainability, as the loss of localised companies could lead to less local sourcing.

Common across all traditional food producers is a need to engage with their practice and to learn from their experience to improve sustainability across all three sustainability dimensions. All traditional food producers face challenges in creating the context for learning and 
constructive engagement with their various suppliers, customers, and regulators who shape practice and performance in the industry.

Over the past 40 years, a practice-based understanding of networks and networking has emerged (Evans, 1965; Trist, 1983; Ring \& Van de Ven, 1992; Worley \& Mirvis, 2013). In the field of operations strategy, defined as reconciling the requirements of the market with the capabilities of operations resources (Slack \& Lewis, 2008), there has been a shift from continuous and strategic improvement within the firm, to collaborative improvement and collaborative strategic improvement between firms (Cagliano, Caniato, Corso, \& Spina, 2002; Coughlan \& Coghlan, 2011).

In the context of this chapter, our particular focus is on relationships among European traditional food producers (TFPs) and the learning networks that may develop and operate sustainably. The chapter describes and reflects upon an EU-funded research initiative, TRADEIT, which has attempted to address this challenge. In particular, the chapter focuses on the development of a learning network among TFPs, across Europe, as one way of contributing to the economic sustainability of the individual ventures, the social sustainability of the regional character of the food, and the environmental sustainability of food production through the use of traditional methods. The chapter is structured as follows: we begin with TRADEIT, the funded research initiative, then explore learning in organizations and networks. Beginning with TRADEIT, rather than a literature background, is meant to acknowledge the origins of the research. While the structure and literature-based foundations of TRADEIT are evident, they are not where the initiative began. Instead, it began with the action on which the learning is based and from which the learning is described. The chapter then outlines the action learning research methodology developed and implemented to explore the development of a learning network in TRADEIT. A single case is presented to illustrate the engagement of small food producers in the network. The discussion reflects on the application of action learning in supporting sustainability within TRADEIT. 


\section{TRADEIT}

TRADEIT, the research activity presented in this chapter, is funded within the EU Seventh Framework programme. It is a multidisciplinary, multi-sectoral collaborative project providing training to stimulate innovation and entrepreneurship among traditional food producers (TFPs) in the dairy, meat, and bakery sub-sectors. TRADEIT is working to establish a network of food producers for the effective transfer of innovative knowledge, processes, and technologies with a view to improving traditional food production. The project comprises nine regional networks (called hubs) across eight European countries: Finland, Germany, Ireland, Italy, Poland, Portugal, Spain (two hubs), and the United Kingdom. The TRADEIT Network at submission was comprised of 19 consortium members and 44 stakeholder associations. The consortium members include food producers, network organisations, and academic research institutions. To date, more than 600 small and medium enterprises (SMEs) have participated in project activities.

The TRADEIT project aims to increase the competitiveness and inter-regional advantage of traditional food producers by means of a durable pan-European network that will build and encourage collaboration between stakeholders in the traditional food sector (e.g., the food producers themselves, food researchers, academic organizations, research institutes, technology providers, national food associations, and business and entrepreneurial networks). The espoused aim of the project is to go beyond achieving limited, though valuable, economic goals of individual firm development to creating and building a learning network of stakeholders that lasts through network action learning. The assumption is that successful collaboration among producers within a network brings with it the potential for a competitive advantage that cannot be gained from the producers working alone (Huxham \& Vangen, 2005). This advantage may arise from collaboration and learning from others how to reduce costs, reach a wider customer base, reduce environmental impact, and strengthen the linkage to local or regional identity. Hence, TRADEIT was designed to deliver a durable network that would benefit the producers 
through overcoming the vulnerability of their small scale and limited resources through networking and learning.

The TRADEIT network comprises researchers from many disciplines and firms from three sectors (bakery, meat, and dairy) in each of nine hubs (spread over eight countries). The network is organized into projects that are divided into a number of work packages, each of which delivers a particular process to help the traditional food producers develop their business and to build the network. These work packages are structured around delivering training to meet challenges, such as knowledge transfer, food safety, food labelling, use of IT, supply chain management, and distribution. A hub advisor within each hub acts as an action learning coach by bringing the network together and facilitating the learning (Pedler \& Abbott, 2013).

\section{LEARNING IN ORGANISATIONS AND NETWORKS}

\section{Learning at home and away}

In recent years, the notion of organizational learning has been extended to encompass the interorganizational setting (Larsson, Bengtsson, Henriksson, \& Sparks, 1998; Lavie, Stettner, \& Tushman, 2010) and learning in and by networks (Knight, 2002; Knight \& Pye, 2004). Network learning involves exploration and exploitation both within firms and between them as they participate in network meetings (Holmqvist, 2003; Coughlan \& Coghlan, 2011). This learning is at home when within organisations and away when between organizations. In the context of sustainability, learning includes away exploration of social, environmental, and economic issues that can then be exploited at home in the firm. There is interaction between learning at home and away as participants learn both within their network and from it (Docherty, Huzzard, de Leede, \& Totterdill, 2003). Such intra-organizational learning favours exploitation while interorganizational learning favours exploration (Holmqvist, 2003). Expressed differently, what is exploited at home then gets explored away, which then feeds back to what is exploited at home 
(Coughlan \& Coghlan, 2011). Shani and Docherty (2003) argue that organization design is critical to building the learning mechanisms to develop and to sustain learning capabilities.

\section{Learning mechanisms}

Organizational learning mechanisms typically refer to planned organizational structures and processes that encourage dynamic learning, particularly to enhance organizational capabilities. Shani and Docherty (2003) present three types of learning mechanisms: cognitive, structural, and procedural:

- Cognitive learning mechanisms provide language, symbols, theories, values, and concepts for thinking about and understanding learning issues.

- Structural mechanisms comprise organizational, physical, and technical infrastructures, such as quality teams, continuous improvement task forces, feedback channels, databases, intranets, document sharing systems, and the physical layout of workspace.

- Procedural mechanisms are the institutionalised procedures that promote and support learning, such as learning meetings and action learning programmes.

These three forms of learning mechanisms shape the design and implementation of a learning network, and consolidate and sustain its learning capabilities into the future. Action learning and action learning research are well positioned to deliver network learning and actionable knowledge through their focus on direct engagement and learning in-action (Coughlan \& Coghlan, 2011; Coghlan \& Coughlan, 2015).

\section{Action Learning}

Action learning is a way of thinking and working that privileges the learning that can be gained from focusing on real life problems of personal consequence to learners. Action learning operates in the realm of practical knowing, where concern is for the applied and where situations are 
dynamic, never identical or replicable. It focuses on what a particular organizational system needs in the present for the future. It works with the language, metaphors, and constructions of participating members. Action learners learn though taking action and reflecting with peers on the action, with the aim of improving their own practice. In the process, individuals can experience transformation in personal perspectives, in social relations, and in management viewpoints (Rigg \& Trehan, 2004).

Action learning occurs in an environment where engaging in questioning is privileged over theoretical knowledge. Revans (2011) presents the following action learning formula: $L=P+Q$, where $\mathrm{L}$ stands for learning, $\mathrm{P}$ for programmed knowledge (i.e., current knowledge in use), and Q for questioning insight. For Revans, learning always begins with Q, where questioning engages the participants and facilitators as to what is occurring throughout the project and frames learning, thereby, extending $\mathrm{P}$. That is not to say that $\mathrm{P}$ (programmed knowledge) is not present in action learning. However, engaging in experimenting, questioning, and reflection $(\mathrm{Q})$ is privileged over 'expert' dissemination of programmed knowledge.

Revans (1971) proposed a theory of action in terms of a science of praxeology, comprising what he called systems alpha, beta, and gamma. In essence, system alpha focuses on the investigation of the problem, based on the managerial value system, the external environment, and available internal resources. System beta focuses on problem resolution, through decisions, cycles of negotiation, and trial and error. System gamma focuses on the learning as experienced uniquely by each of the participants through their self-awareness and questioning. The three systems alpha, beta, and gamma are not linear or sequential, nor are they entirely discrete. Rather, they overlap on important issues of learning, power, and politics. They emphasise how action learning involves engagement with real issues. The engagement is both scientifically rigorous in confronting the issues and critically subjective through managers learning in action. 
Action learning provides the basis for critical inquiry as it generates insights into how learning is realized (Rigg \& Trehan, 2004). In this research, we ask: what can the building of a learning network in TRADEIT achieve for traditional food producers, and what insights emerge that inform future action and research into the development of collaborative relationships and the building of a robust learning network among firms? The prospective insights are of relevance to both the traditional food producers and the researchers in the TRADEIT network.

\section{METHODOLOGY: ACTION LEARNING RESEARCH}

Traditionally, action learning has been directed toward enabling professionals to learn and develop by reflecting on their own experience in the company of peers, as they seek to address real-life problems in their own organizational settings. What has received less attention is how action learning may constitute an approach to research. Coghlan (2011; Coughlan \& Coghlan, 2011) argues that action learning research may be located in the family of action-oriented approaches to inquiry, such as action research (Greenwood \& Levin, 2007) and collaborative management research (Shani, Mohrman, Pasmore, Stymne, \& Adler, 2008; Hoes, Regeer, \& Joske, 2008). Consequently, action learning research seeks to enable learning among the food producers in their hubs and researcher networks as well as the generation of actionable knowledge that can build and sustain such networks.

Research through action learning may be positioned within contemporary expressions of alternatives to traditional research paradigms, especially Mode 2 research, defined by Gibbons and his colleagues (1994) as a network activity different from a model embedded in the expertise of isolated individuals operating from a top-down expert perspective. Mode 2 research knowledge is characterised contextuality, transdisciplinarity, heterogeneity, organizational diversity, social accountability, and reflexivity. A number of the features attributed to Mode 2 are applied to such established action-oriented approaches as action learning and action research (MacLean, MacIntosh, \& Grant, 2002). Intended empirical outputs from the project are an action 
learning research-based understanding of how each traditional food producer, in its own local and market context, learns how to improve its supply chain collaboration, innovation, entrepreneurship, knowledge and technology transfer, and how a durable network may be constructed.

Action learning research provides a basis for critical inquiry as it generates insights into tensions, contradictions, emotions, and power dynamics in and between organizations (Rigg \& Trehan, 2004; Vince 2004; Coughlan \& Coghlan, 2011). The actionable knowledge generated needs to meet the criteria of good research. It should be rigorous, reflective, and relevant (Pasmore, Woodman, \& Simmons, 2008). Quality in action learning research requires that the collaborative engagement with real-life issues towards workable outcomes has a reflective character while being rigorously objective with reference to a wide set of criteria about the facts of the problem and its context.

Action learning in TRADEIT acts as a coordinating and a learning mechanism:

- It acts as a learning mechanism in enabling participating food producers to engage in questioning and reflection in their networks in order to develop skills for learning-inaction.

- It acts as an integrating mechanism across the work packages such that interconnections between the training and knowledge transfer became evident and are reinforced, rather than them being standalone activities.

In this way we are ensuring that action learning underpins all network activities and that the network operates in a very particular way to involve more group and individual reflection than might otherwise be the case.

The authors' role, as leaders of the action learning and action learning research processes, was to act as members and learning advisers for the project management board and the hub advisers, as well as to contribute on-going support for development of network durability. This involved developing the action learning capacity of the hub advisers to facilitate action learning 
activities for the food producers through provision of facilitator training. In terms of action learning research, they acted as organisers and conduits for the capture and dissemination of the knowledge gained within the hubs.

Figure 1 outlines the multiple roles of action learning research coordinators. At the regional hub level there is meeting preparation and the availability of tools. The hub learning advisers were trained in action learning to enable them to engage with the food producers in their hubs. The hub advisors provided reports of the hub meetings and the reflections on how they went and how the participating producers expressed their learning.

[Insert Fig. 1 here]

\section{Developing a Learning Network In TRADEIT}

During the second year of the project, the participants found a sample case account to be very useful. The case had been written by the authors in their role as facilitators of the action learning process to provide an example of how one particular food producer was engaging in and learning through TRADEIT. Reflecting on this experience, they decided to invite the hub advisors to work with the food producers in their hubs to produce short case accounts of their learning experiences. A guide to action learning case writing was provided for the hub advisors. The hub advisors and their respective food producers responded enthusiastically and produced a series of rich case accounts that captured their learning.

In developing the case accounts, training sessions were held for hub advisors. Google Hangouts were held to introduce the hub advisors to case writing guidelines and to explore case writing opportunities within each hub. The hub advisors developed draft cases and these drafts were presented and discussed at a hub advisor case writing workshop. A second Hangout was held with hub advisors to continue case development and to share experiences and insights. 
Following a brief "show \& tell," the hub advisors were facilitated in a discussion of the case accounts individually and as a group in relation to TRADEIT.

\section{THE GLUTEN FREE KITCHEN COMPANY LTD.: \\ “THE POP-UP THAT DIDN'T CLOSE"}

TRADEIT engages with TFPs in three sectors: bakery, meat, and dairy. In eight of the hubs, ten cases focused on traditional artisan bakeries. One of the bakeries, located in Ireland, is The Gluten Free Kitchen Company, Ltd.

Following a lifetime of living with the effects of the auto-immune coeliac disease, and prompted by her experiences where nutritious and tasty products for coeliac and allergy sufferers were unavailable, Doireann Barrett set up The Gluten Free Kitchen Company Ltd (TGFKC) in November 2011.

I opened as a pop-up (or temporary market stall) in a shopping centre in Tralee, a small town of 25,000 people in south-western Ireland. My plan was to test the market with gluten-free fresh-baked products including breads, cakes, Christmas puddings, mince pies, and Christmas cakes.

Within a week of setting up the stall, TGFKC gained its first contract to supply a local health food store with daily deliveries of fresh bread, which was quickly followed by other trade orders. Four months later, March 2012, Doireann moved TGFKC into a vacant fully-equipped restaurant unit to expand her capacity. During the first year of operation, the company expanded its range of fresh-baked gluten-free products and also tested the market for a restaurant and deli takeaway unit. At this stage, the business was innovating through customer feedback and recipe suggestions.

Quality ingredients and gluten free remained at the heart of the company's range. I found new sources of innovation and refinement from attendance at a top cookery school in Ireland and from my business partner, an experienced executive chef. 
As the second anniversary of the company approached, Doireann gave up the restaurant premises rather than be tied into a new 5-year lease in a less-than-ideal location. She moved TGFKC to the city of Cork to take advantage of a three-month business development programme for high potential start-ups. TGFKC was one of eight companies selected out of 180 applicants to participate and receive intensive support to develop the company concept.

I found the focus of this programme didn't fit. It was based on a philosophy of encouraging participants to concentrate on a limited number of products in order to scale up production and target large markets. Consequently, I withdrew.

By mid-2014, TRADEIT project events for SMEs started and Doireann attended workshops in Ireland, Germany, and Italy focusing on competitiveness, cost models, pricing strategies, scaling the business - distribution channels and opportunities, and supply chain and distribution networks.

Participation has enabled me to pull back from the day-to-day. I found the workshop content to be useful for reflection, particularly hearing the stories of other traditional food producers even though they might be in other sectors. I recognised that TGFKC had grown too quickly in year one, having started with no grant or bank support, and financial investment for cash flow.

Doireann developed her networking skills, which expanded her sense of who she was connected to, and learned to reach out to other types of businesses instead of just seeking information from other gluten free producers:

I had felt very unique and it was difficult to meet anyone who was producing nutritious and trustworthy gluten free products on a small scale. Through TRADEIT, I came to realise that I am connected to others, such as an organic food producer, by the notion of producing good, nutritious foods. I made useful contacts locally at some of the events, including the owner of a local bakery to whom I can bring my questions. Another larger local baker buys packaging material in bulk, and now I buy what I need from him so avoiding having to purchase excessive minimum quantities myself.

Participating in a German event, as a speaker as well as an attendee, helped Doireann in her reflections, both as she prepared for the presentation and through the numerous questions asked by other participants. 
I enjoy being around like-minded people with great craft and passion both for getting a quality food product into the market and for meeting their customers. I found it interesting to learn that, like me, other food producers were being overshadowed by mass producers. It has been interesting also to hear how regulations for gluten-free production in some other countries are much stricter, with the consequence that there are fewer gluten-free producers in there.

Through TRADEIT Doireann gained a deeper understanding of her own venture.

Connecting with other traditional food entrepreneurs in Ireland and across Europe has reaffirmed my confidence in the value of my knowledge, including needs of an allergy sufferer, the market potential for gluten-free and wheat-free products, product ingredients and process, how to avoid cross-contamination, and limitations of the support systems for achievement of compliance.

At the time of writing this chapter, Doireann had completed the business plan for the next phase of development of TGFKC, which is to license the brand and to open a chain of outlets.

I have business model packages to suit small (kiosk), medium (cafe) and large (restaurant) outlets. I am in discussions with investors and potential licensees and am developing a further phase of my plan, which is to open a central production unit to service branded kiosk sales and distribution in the future.

This phase of development will challenge TGFKC to think systematically about sustainability, including the evolution in plant role, the organisational revolution that may be required to produce and compete in this new configuration, the codification of existing procedures, and the balancing of the inevitable structural changes with the associated costs of infrastructure. In the meantime, TGFKC continues to supply a number of restaurants, food and music festivals, and local private clients.

\section{DISCUSSION}

In this research, we asked, "What can building a learning network in TRADEIT achieve for the traditional food producers, and what insights emerge that inform future action and research into the development of collaborative relationships and the building of a durable learning network 
among firms?" The discussion is organised in three parts. In the first part, we reflect on the challenges faced by traditional food producers (TFPs) in the TRADEIT project and the particular case description of TGFKC. In the second part, we reflect on the role of action learning as a mechanism for developing learning in the network and as a research methodology. Finally, we consolidate our reflections on the application of action learning to supporting sustainability of traditional food producers through building a learning network.

\section{Challenges faced by Traditional Food Producers}

The case of one of the bakeries engaged in action learning within TRADEIT, The Gluten Free Kitchen Company Ltd., tells its own distinctive story. In addition, as a case within TRADEIT, it captures and illustrates many of the issues faced by the wider set of TFPs.

All of the bakeries participating in TRADEIT developed as owner-run and family enterprises, some over a number of generations. All have a local or regional distinctiveness or character. Examples of the challenges related to the sustainability of these bakeries are categorised in terms of an innovation management process model (Chiesa, Coughlan, and Voss, 1996), and summarised in Table 1. The core process of innovation consists of five sub-processes: product innovation, product development, process innovation, technology acquisition, and market focus. Innovation does not happen in a vacuum. Leadership, resourcing, and the use of appropriate systems and tools enable the core process of innovation. This process model is at the firm level. Here, the management, the process activities, and the decisions and responses required to take a product from concept to market impact innovation performance, firm competitiveness, and sustainability.

\section{[Insert Table 1 here]}

The innovation challenges faced by the bakeries in TRADEIT include how to develop innovative products that build on traditional baking and reflect regionality. Similar challenges 
are faced by other small enterprises. However, engaging in innovation and development as a small firm can be difficult due to a lack of resources and capabilities, and SMEs cannot overcome this challenge alone. They must engage in open innovation practices where they utilise knowledge and expertise from both inside and outside their firms (Lee, Park, Yoon, \& Park, 2010). These practices are dependent on establishing collaborative relationships with other organisations (Chesbrough, Vanhaverbeke, \& West, 2006). Therefore, the bakeries in TRADEIT need to develop partnerships for market focus and development. They needed to acquire technology to develop and optimise production processes, food labelling, and packaging for longer shelf life. Finally, they needed to develop the confidence to take a lead in defending a local vision for their products. For some, this vision included an ambition to grow beyond their regional boundaries.

As outlined also in Table 1, the challenges faced by the bakeries in TRADEIT were split into two broad categories: (1) technical and operational and (2) organisational and cultural. The technical and operational challenges ranged from understanding customer needs through optimising processes to sourcing technology. The organisational and cultural challenges extended from network development through maintaining culture and identity, to understanding other TFPs.

As a set, these challenges are evident in the TGFKC experience of product development, facilities expansion, sourcing of packaging, and maintaining a set of ingredients that conform to gluten-free labelling standards. In contrast, the organisational and cultural issues are evident in the benchmarked insights into novel and distinctive food production and firm development, through Doireann's local and international access to a network of other food producers. However, the TGFKC case illustrates that this access is complemented by an emergent selfconfidence in and understanding of the distinctiveness of TGFKC as a food producer leading to the recognition that the enterprise could profit from outsourcing new intellectual property. Doireann exploited a number of practices that are used by enterprises to acquire knowledge from 
outside their firms, including customer involvement and external networking (van de Vrande, de Jong, Vanhaverbeke, \& de Rochemont, 2009). She also recognised that other firms cannot depend solely on internal research and development activities, and therefore are open to licencing or buying the knowledge she has generated (van de Vrande et al., 2009). As highlighted by Chiaroni et al., (2011) enterprise engagement in networks that include research institutions, universities, suppliers, and users is a key aspect of supporting innovative practices within such firms, as it supports the inflow of knowledge and technology. Indeed, as a project, TRADEIT has facilitated this type of external networking and in doing so, has enabled the synthesis of the two categories of challenges (highlighted in Table 2) in a way that goes beyond a dominant focus on either food science or network development. Innovative practices have been shown to increase productivity in SMEs (Mañez, Rochina-Barrachina, Sanchis, \& Sanchis, 2013), suggesting that TRADEIT, by supporting innovation within SMEs, can lead to their increased sustainability.

\section{The Role of Action Learning}

It is possible to learn about theory, but it is only in attempting to apply that theory in practice or to explain experience through the insights from theory, and in reflecting on the process, that real and useful learning occurs. In recognition of this, TRADEIT is underpinned by Revans' premise that "learning to act effectively is also learning how to learn effectively" (1980, p. 227) and accordingly, action learning played an important role from initial design stages to execution. It was highlighted previously that SMEs may not be aware of their lack of knowledge on best practice or may not be able to articulate the issues they face (van de Vrande et al., 2009). Because action learning utilises both $\mathrm{P}$ (programmed knowledge) and Q (questioning insight), TRADEIT network members were exposed to best practice (P) through the workshops, networking events, an online newsletter, and were also given space and time for $\mathrm{Q}$ where they discussed, learned to 
articulate, and addressed the real and current problems they faced. While TRADEIT was set up to enable this process and outcome through action learning, the specific technical, operational, organisational, and cultural insights emerging from the interactions and questioning could not have been anticipated. Thus, through action learning, TRADEIT provided a way forward through individuals coming together and learning through action, learning from and with others, and gaining new insight through asking and answering challenging questions.

TRADEIT has enacted Revans' theory of action and his praxeology of cyclical systems - alpha, beta and gamma. In the case of TGFKC, system alpha situated each of the problems faced by the company within its internal and external historical, cultural, managerial, political, and fiscal context. For Doireann, this meant reflecting on her own values and managerial strategy, the history and fast growth of her business, the external regulatory environment, the competitive landscape, and her business model.

System beta involved exploring how opportunities might be exploited or problems resolved through cycles of action and reflection in the network. Food producers in TRADEIT focused on addressing issues, such as the optimisation of their production process, developing new products that reflect regionality, developing partnerships for product and market development, accessing funding, reconciling the use of technology with traditional baking methods, and environmental sustainability. Building on the initial framing of the problem or opportunity in system alpha, a rich description developed, including how the problem was framed initially, what initial actions were planned, how they were implemented, how understanding of the problem evolved, and how cycles of action and reflection were undertaken. TGFKC enacted system beta through Doireann's interactions with other food producers and hub advisors which stimulated the redesign of her business model. This redesign will help her move from local to regional to international distribution.

Action learning incorporates not just the understanding and solving of the problem but also the development of learning by the participating food producers. In TRADEIT, the food 
producers explored the apparent dichotomy between business expansion to ensure economic sustainability while still maintaining traditional methods to ensure regional identity and social sustainability. For TGFKC and Doireann, an enactment of system gamma meant recognition of her connectedness to others, a deeper understanding of her business and her sector, and a better view of "what's next." Each TFP, depending on the issue on which they chose to focus and on the context within which they operated, gained different types of learning. This learning is the particular focus of system gamma. Through action and reflection, both at home in the TFPs and away in the network activities, the TFPs were enabled to change thought processes and TRADEIT evolved into a learning network.

\section{Building a Durable Learning Network through Action Learning}

Network learning involves exploration and exploitation of learning both within firms and between them as they participate in network activities (Coughlan \& Coghlan, 2011). In a learning network, participants share activities and articulate experiences that exploit learning opportunities in an away setting while participants test out their learning at home. Through the cyclical systems, alpha, beta, and gamma, characteristic of the action learning approach, TRADEIT provided a way forward as it involved individuals coming together and learning through action, learning from and with others, gaining new insight through asking and answering challenging questions, and creating a multiplier effect between individual and organizational learning (Rigg \& Trehan, 2004). Thus, the case accounts, such as TGFKC, captured the practice of the TFPs at home. In sharing the cases with the other TFPs, they subjected their accounts and reflections on experience of TRADEIT activities to questioning away. In response, they brought their case accounts home again for a sharper consolidation of their learning.

Figure 2 visualizes the cyclical systems, alpha, beta, and gamma, as interlocking cogs. At the network level in TRADEIT, system alpha is focused on the identification and examination of problems or opportunities facing the traditional food producers in the context of the food 
industry. Within this context, competitiveness at firm level depends upon balancing technology needs for expansion with the constraints of regulatory change, particularly in relation to environmental sustainability. The problems (and opportunities) within this context are at both firm and network levels. At the firm level, the problems include understanding customer needs, maintaining commitment to natural ingredients, developing new products, maintaining culture and identity, optimising processes, and sourcing technology. For a small firm, operating in isolation, these problems represent significant challenges that, if not overcome, may undermine the sustainability of the venture. At the network level, the opportunities for individual firms include the understanding of other TFPs, the positioning of the firm within the character of the region, and the ongoing development of the network as a supportive setting within which to learn and to share experience.

System beta involves cycles of taking action to address identified problems in the context and evaluating that action in light of information from system alpha. These cycles of action take place through the exploration and exploitation at home in the firms and away in the network. The creation of spaces for reflective conversations among the firms in the network enables the peer learning dynamics of the action learning approach to connect L, P, and Q. The result is the enactment of a learning network.

System gamma connects with systems alpha and beta, with a focus on the learning that emerges through action and reflection both at home in the TFPs and away in the network activities. The learning spans collaborative improvement that fits with the firm level problems in the context of the industry and covers the sustainability of the networking among the firms through the learning that emerges from their productive, supportive, and innovative interactions.

[Insert Fig. 2 here] 
Systems alpha, beta, and gamma create a multiplier effect between organizational and network learning. Network learning mechanisms enable the synthesis of the technical, operational, organisational, and cultural dimensions of TFPs towards developing a learning network. Table 2 tabulates how the three forms of learning mechanisms shape the design and implementation of TRADEIT as a learning network and how they consolidate and sustain its learning capabilities into the future. Operating in isolation, the firms can plan their organizational structures and procedures to encourage dynamic learning and enhance their organizational capabilities. However, they may or may not realise their potential for sustainability without engagement with the learning network. Here, it is the cognitive mechanism that recognises and validates the identity and capability of the individual firms while it also creates the space and trust necessary to acknowledge and value the learning potential from interaction.

[Insert Table 2 here]

\section{CONCLUDING REMARKS}

The concept of inter-locking cogs highlights the need for some ongoing force to enable durability. This insight seems obvious once stated but is ignored in much network literature. Perhaps, the absence is attributable to structuralist thinking - once a network is created it is a thing that exists. In contrast, from a process-relational perspective, networking is a verb, a process, a dynamic that does not happen in a vacuum. As such, there cannot be energy equilibrium (self-sustainability); rather, there must be some ongoing force. Therefore, in a system of interlinked cogs, for the cogs to begin to move there must be an impetus or force that generates that movement.

In the case of TRADEIT, the initial impetus to set up the network was European funding.

Of course, a learning network may develop and progress without specific funding. However, in 
the context of the food industry where traditional food producers are opportunity-rich but resource-poor, their capacity to engage may be limited without the allocation of directed funding. TRADEIT has been funded in such a way as to create the learning mechanisms to underpin the learning network. The funding has been directed at both skills development and firm interaction, both of which are necessary for sustainability. However, external funding is transitory in nature. Therefore, if the cogs are to continue to turn and the network as initially supported is to last, there must be ongoing and deliberate application of learning mechanisms.

Action learning is a means of creating "new webs of connections and ways of organising between people" (Pedler and Abbott, 2013, p. 143). Thus far, the new connections and ways of working that have been stimulated by action learning activities in TRADEIT have provided the lubricant for the cogs to turn smoothly and steadily. The result is that leaning is occurring at the individual level, the organisational level, and the inter-organisational level. It has been demonstrated that both formal networks and informal networking activities can help enterprises increase innovation and exploit technology since by engaging with others, small firms can avoid the large financial and resource investment that might otherwise be required to address their knowledge needs (van de Vrande et al., 2009). We have seen evidence of this increase in TRADEIT, as highlighted by the case study.

As a strategic network, TRADEIT was set up initially to help traditional food producers exploit their ambition to grow and develop through innovation. The network comprises researchers from many disciplines, and firms from three sectors (bakery, meat, and dairy) in each of nine hubs spread over eight countries. As the project progressed, action learning facilitated the emergence of a learning network, different from the original collection of firms who agreed to participate in the project. From that early set of disconnected ventures, the partners now form a network within which experience is shared, questions are asked, and through reflection, insight and actionable knowledge are generated at individual and organisational levels. The involvement of both researchers and practitioners in the action learning process in this network ensures 
commitments to both action and learning in a context where all participants are actors and inquirers. The focus is on real issues faced by participants. However, learning is not limited to the level of individual participants and organisations. Traditional food producers all face similar issues: they are small, often struggle to compete against larger food producers, and frequently find it difficult to reconcile expansion and growth with a traditional ethos. Thus, interorganisational learning is occurring in cycles of action learning as the actionable knowledge that is generated in response to an issue faced by one organisation has application to issues faced by others. Firms in the network are exploiting this knowledge to address their issues and to develop and grow and simultaneously TRADEIT has matured from a network of disconnected individuals to a learning network characterised by knowledge sharing, co-creation, and learning.

It can be difficult for SMEs, individually, to seek out appropriate partners for collaboration. An intermediary, often in the form of a public authority, can take on this role. The intermediary can also take on the role of network construction and management as these are activities that individual SMEs have neither the time nor inclination to undertake (Lee et al., 2010). The TRADEIT project, supported by EU funding, has acted as such an intermediary. The project is ongoing; therefore, it is impossible to anticipate whether the learning network, which has been initiated, supported, and developed with the support of external funding and the TRADEIT governance structure, will last without this structure and support. However, what is clear is that relationship development and transformation occurred at the level of individual firms, highlighting the potential for relationships between network members to extend beyond the lifetime of the funding. This brings with it the promise of greater stability for the network and greater sustainability for individual member firms. 


\section{ACKNOWLEDGEMENT}

The research in this paper is undertaken as part of TRADEIT, FP7-KBBE. 2013.2.3-02 Network for the transfer of knowledge on traditional foods to SMEs; Coordinator: Institute of Technology Tralee, Tralee, Co Kerry, Ireland. Funded by the EC (Grant No: 613776). $\underline{\text { www.tradeitnetwork.eu }}$ 


\section{REFERENCES}

Cagliano, R., Caniato, F., Corso, M., \& Spina, G. (2002). Fostering collaborative improvement in extended manufacturing enterprises: A preliminary theory. In R. Smeds (Ed.), Continuous Innovation in Business Processes and Networks (pp. 131-143). Espoo, Finland: Helsinki University of Technology.

Chesbrough, H., Vanhaverbeke, W., \& West, J. (2006). Open Innovation: Researching a New Paradigm. New York, NY: Oxford University Press.

Chiaroni, D., Chiesa,V., \& Frattini, F. (2011). The open innovation journey: How firms dynamically implement the emerging innovation management paradigm. Technovation, $31(1), 34-43$.

Chiesa, V., Coughlan, P., \& Voss, C. (1996). Development of a technical innovation audit. Journal of Product Innovation Management, 13(2), 105-136.

Coghlan, D. (2011). Action learning research: The philosophy and methodology of practical knowing. In M. Pedler (Ed.), Action Learning in Practice (4 ${ }^{\text {th }}$ ed., pp. 357-367). Farnham, UK: Gower.

Coghlan, D., \& Coughlan, P. (2015). Effecting change and learning in networks through network action learning. Journal of Applied Behavioral Science, 51(3), 375-400.

Coughlan, P., \& Coghlan, D. (2011). Collaborative Strategic Improvement through Network Action Learning: The Path to Sustainability. Cheltenham, UK: Edward Elgar.

Docherty, P., Huzzard, T., de Leede J., \& Totterdill, P. (2003). Home and away: Learning in and learning from organisational networks in Europe. Brussels, EU: Innoflex Research Report. Retrieved from http://j.mp/InnoFlex

Evans, W. M. (1965). Toward a theory of inter-organizational relations. Management Science, 11, 217-230.

FoodDrink Europe. (2013). Data and Trends of the European Food and Drink Industry 2012. Brussels: FoodDrink Europe. 
Gibbons, M., Limoges, C., Nowotny H., Schwartzman, S., Scott, P., \& Trow, M. (1994). The New Production of Knowledge. London: Sage Publications.

Greenwood, D., \& Levin, M. (2007). Introduction to Action Research (2 ${ }^{\text {nd }}$ ed.). Thousand Oaks, CA: Sage.

Hoes, A-C., Regeer, B.J., \& Joske, F. (2008). Transformers in knowledge production: Building science-practice collaborations. Action Learning: Research and Practice, 5(3), $207-$ 220.

Holmqvist, M. (2003). A dynamic model of intra- and interorganizational learning. Organization Studies, 24(1), 95-123.

Huxham, C., \& Vangen, S. (2005). Managing to Collaborate: The Theory and Practice of Collaborative Advantage. London: Routledge.

Knight, L. (2002). Network learning: Exploring learning by interorganizational networks. Human Relations, 55(4), 427-454.

Knight, L., \& Pye, A. (2004). Exploring the Relationship between Network Change and Network Learning. Management Learning, 35(4), 473-490.

Larsson, R., Bengtsson, L., Henriksson, K., \& Sparks, J. (1998). The interorganizational learning dilemma: collective knowledge in strategic alliances. Organization Science, 9, 285-306.

Lavie, D., Stettner, U., \& Tushman, M. (2010). Exploration and exploitation within and across organizations. Academy of Management Annals, 4(1), 109-155.

Lee, S., Park, G., Yoon, B., \& Park J. (2010). Open innovation in SMEs - An intermediated network model. Research Policy, 39(2), 290-300.

MacLean, D., MacIntosh, R., \& Grant S. (2002). Model 2 management research. British Journal of Management, 13(3), 189-207.

Mañez, JM., Rochina-Barrachina, M.E., Sanchis, A., \& Sanchis, J.A. (2013). Do process innovations boost SMEs productivity growth?. Empirical Economics, 44(3), 13731405. 
Pasmore, W.A., Woodman, R.W., \& Simmons, A.L. (2008). Toward a more rigorous, reflective and relevant science of collaborative management research. In A.B. Shani, S.A. Mohrman, W.A. Pasmore, B. Stymne, \& N. Adler (Eds.), Handbook of Collaborative Management Research (pp. 567-582). Thousand Oaks, CA: Sage Publications.

Pedler, M., \& Abbott, C. (2013). Facilitating Action Learning. Maidenhead: McGraw-Hill. Revans, R.W. (1971). Developing Effective Managers. New York: Praeger.

Revans, R.W. (1980). Action Learning: New Techniques for Management. London, UK: Blond and Briggs, Ltd.

Revans, R.W. (2011). ABC of Action Learning. Farnham, UK: Gower

Rigg, C., \& Trehan, K. (2004). 'Reflections on working with critical action learning. Action Learning: Research and Practice, 1(2), 149-166.

Ring, P.S., \& Van de Ven, A.H. (1992). Structuring cooperative relationships between organizations. Strategic Management Journal, 13(7), 483-498.

Savitz, A.W., \& Weber, K. (2006). The Triple Bottom Line: How Today's Best-Run Companies are Achieving Economic, Social, and Environmental Success-and How You Can Too. San Francisco, CA: Jossey-Bass.

Shani, A.B., \& Docherty, P. (2003). Learning by Design: Building Sustainable Organizations. Oxford: Blackwell Publishing.

Shani, A.B., Mohrman, S.A., Pasmore, W.A., Stymne, B., \& Adler, N. (Eds.) (2008). Handbook of Collaborative Management Research (pp. 567-582). Thousand Oaks, CA: Sage Publications.

Slack, N., \& Lewis, M. (2008). Operations Strategy (2 $2^{\text {nd }}$ ed.). Harlow, UK: FT Prentice-Hall. Trist, E. (1983). Referent organizations and the development of inter-organizational domains. Human Relations, 36(3), 269-284. 
van de Vrande, V., de Jong, J. P. J., Vanhaverbeke, W., \& de Rochemont, M. (2009). Open innovation in SMEs: Trends, motives and management challenges. Technovation, $29(7), 423-437$.

Vince, R. (2004). Action learning and organizational learning: Power, politics and emotions in organisations. Action Learning: Research and Practice, 1(1), 63-78.

Worley, C. \& Mirvis, P. (2013). Building Networks and Partnerships (Organizing for Sustainable Effectiveness, vol. 3). Bingley, UK: Emerald Group Publishing Limited. 
Fig. 1. Roles of action learning research coordinators

\section{Hub Level}

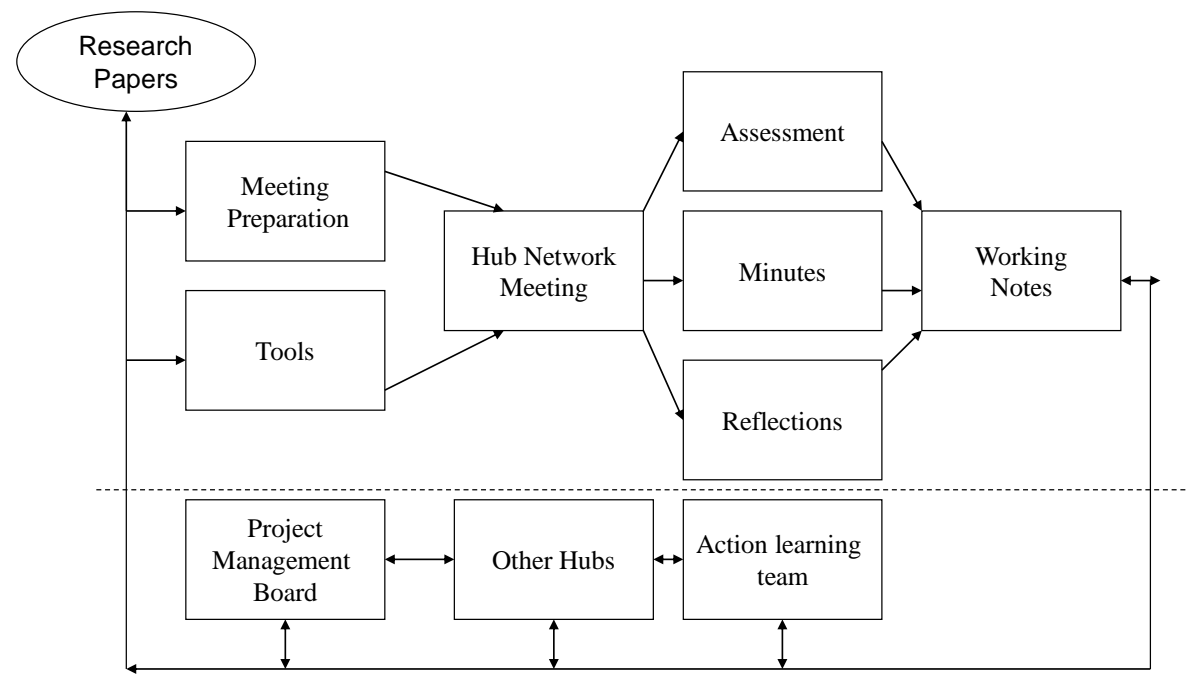


Fig. 2. Added Value of Action Learning in the TRADEIT network:

\section{Application of Revans' Systems Alpha, Beta and Gamma}

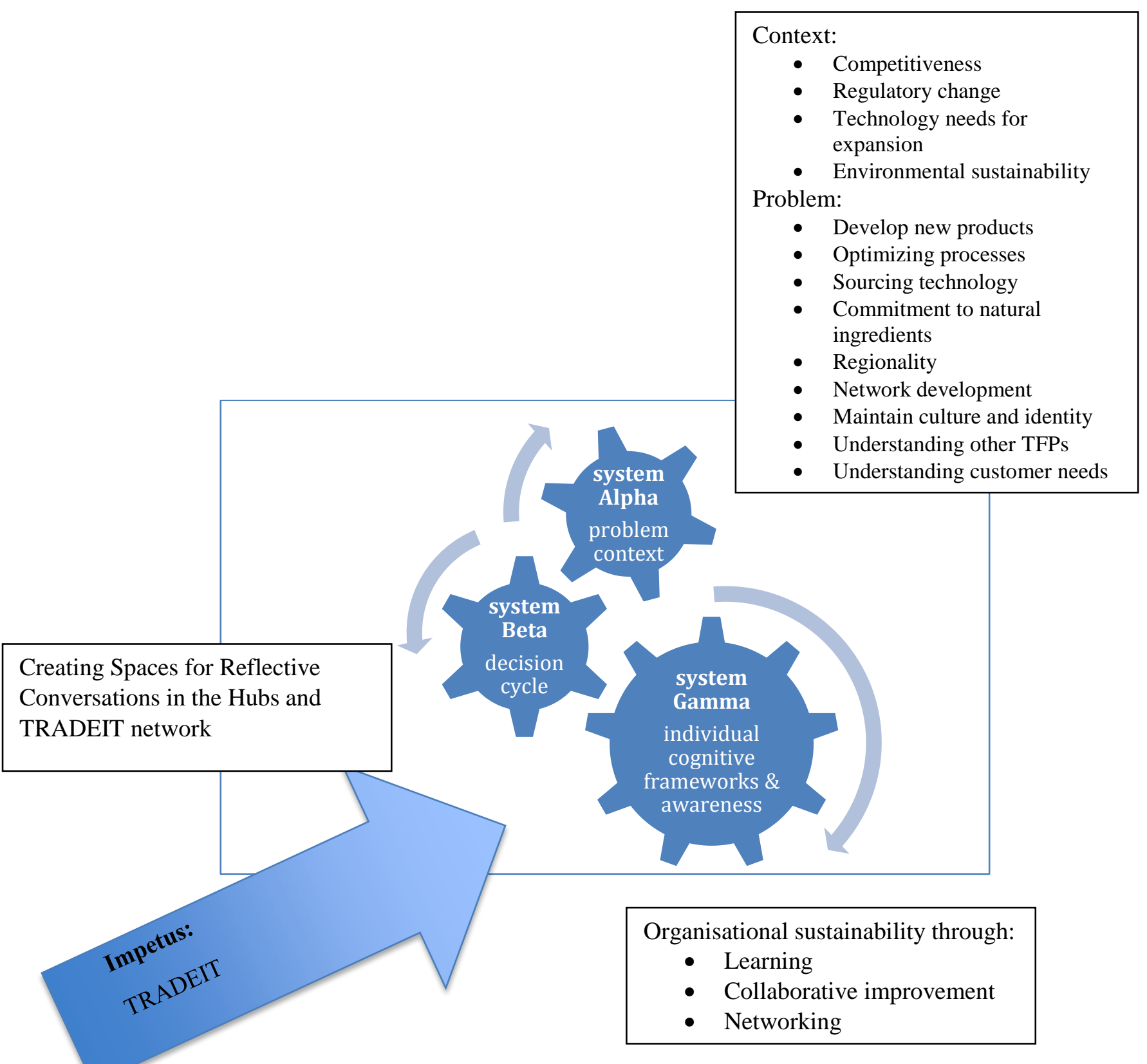


Table 1. Challenges reported in traditional food producers

\begin{tabular}{|c|c|c|}
\hline Innovation Process & Challenges faced & $\begin{array}{c}\text { Character of the } \\
\text { challenges }\end{array}$ \\
\hline \multicolumn{3}{|l|}{ Core Process } \\
\hline Product innovation & $\begin{array}{l}\text { - Novel recipes with natural } \\
\text { ingredients }\end{array}$ & \multirow{5}{*}{$\begin{array}{c}\text { Technical and } \\
\text { operational }\end{array}$} \\
\hline Product development & - $\quad$ Develop new products & \\
\hline Process innovation & - Labelling & \\
\hline Technology acquisition & $\begin{array}{l}\text { - } \text { Sourcing technology } \\
\text { - } \\
\text { Optimising processes }\end{array}$ & \\
\hline Market focus & $\begin{array}{l}\text { - Understanding customer } \\
\text { needs } \\
\text { - Understanding other TFPs }\end{array}$ & \\
\hline \multicolumn{3}{|l|}{ Enabling Process } \\
\hline Leadership & $\begin{array}{ll}\text { - } & \text { Maintain culture \& } \\
& \text { identity } \\
\text { - } & \text { Regionality, } \\
\text { innovativeness, traditional } \\
\text { - } & \text { Environmental } \\
& \text { sustainability }\end{array}$ & \multirow[t]{2}{*}{$\begin{array}{c}\text { Organisational and } \\
\text { cultural }\end{array}$} \\
\hline Resources & - Network development & \\
\hline Systems \& tools & - Benchmarking & \multirow{2}{*}{$\begin{array}{c}\text { Technical and } \\
\text { operational }\end{array}$} \\
\hline Performance & - $\quad$ Certified benefits & \\
\hline
\end{tabular}


Table 2. Network Learning Mechanisms in TRADEIT

\begin{tabular}{|c|c|}
\hline Mechanism & Learning Opportunity \\
\hline Cognitive & $\begin{array}{l}\text { - Recognition of TRADEIT as an opportunity to share } \\
\text { and to identify emergent values } \\
\text { - Acknowledgment of learning potential from interaction }\end{array}$ \\
\hline Structural & $\begin{array}{l}\text { - TRADEIT as an opportunity for shared human } \\
\text { resource development } \\
\text { - TRADEIT intranet, online marketplace database as the } \\
\text { basis for a durable learning network }\end{array}$ \\
\hline Procedural & $\begin{array}{l}\text { - TRADEIT workshops and brokerage events as learning } \\
\text { meetings }\end{array}$ \\
\hline
\end{tabular}

